\title{
IMPLEMENTASI STRATEGI MATHEMATICAL HABITS OF MIND (MHM) BERBANTUAN MULTIMEDIA UNTUK MENINGKATKAN KEMAMPUAN BERPIKIR KRITIS SISWA
}

\author{
Hedi Budiman ${ }^{1}$, Igfania Esvigi ${ }^{2}$ \\ ${ }^{1}$ Universitas Suryakancana \\ hedi@unsur.ac.id \\ ${ }^{2}$ Universitas Suryakancana \\ igfaniaesvigi@gmail.com
}

\begin{abstract}
ABSTRAK
Strategi Mathematical Habits of Mind (MHM) adalah strategi pembelajaran yang membiasakan siswa untuk berpikir matematis dengan beberapa aktivitas seperti: mengeksplorasi ide-ide matematis; merefleksi kebenaran atau kesuaian jawaban; generalisasi dan mengidentifikasi strategi penyelesaian masalah yang dapat diterapkan pada masalah lain; memformulasi pertanyaan; dan mengkonstruksi contoh. Penelitian ini bertujuan untuk mengkaji peningkatan kemampuan berpikir kritis siswa melaluipenggunaan strategi pembelajaran Mathematicals Habits of Mind (MHM) berbantuan multimedia. Penelitian ini merupakan kuasi eksperimen dengan Pretest Posttest Control Group Design. Subjek penelitian adalah siswa salah satu SMA Negeri di Cianjur dengan subjek sampel siswa kelas $\mathrm{X}$ sebanyak dua kelas yang dipilih dengan teknik purposive sampling.Kelas eksperimen menggunakan strategi pembelajaran Mathematicals Habits of Mind (MHM) berbantuan multimedia dan kelas kontrol menggunakan pembelajaran saintifik. Hasil penelitian menunjukan bahwa peningkatan kemampuan berpikir kritis matematis kelas eksperimen lebih baik daripada kelas kontrol. Siswa yang mendapatkan strategi pembelajaran Mathematicals Habits of Mind (MHM) berbantuan multimedia menunjukkan sikap positif. Rata-rata gain ternormalisasi siswa pada kelas eksperimen tinggi dan sedang, sedangkan kelas kontrol pada kategori sedang dan rendah. Selisih gain ternormalisasi pada kelas eksperimen lebih baik daripada kelas kontrol.
\end{abstract}

Kata Kunci: Berpikir Kritis Matematis,Strategi Mathematical Habits of Mind (MHM), Multimedia

\section{PENDAHULUAN}

Meningkatkan kemampuan berpikir kritis matematis pada siswa merupakan hal penting yang perlu dilakukan guru pada pembelajaran matematika. Menurut Glaser (2004), berpikir kritis sebagai: a) Suatu sikap mau berpikir secara mendalam tentang masalah-masalah dan hal-hal yang berbeda dalam jangkauan pengalaman seseorang; b) Pengetahuan tentang metode-metode pemeriksaan dan penalaran yang logis; c) Suatu keterampilan untuk menerapkan metode-metode tersebut. Costa (2001) menyatakan individu yang berpikir kritis memiliki ciri-ciri diantaranya adalah mendeteksi permasalahan, mampu membedakan informasi- 
informasi, suka mengumpulkan data untuk pembuktian faktual, mampu membuat hubungan yang berhubungan antara satu masalah dengan masalah lainnya, mampu mendaftar alternatif pemecahan masalah dengan masalah lainnya, mampu menarik kesimpulan dan generalisasi dari data yang ada.

Berpikir kritis adalah proses mental untuk menganalisis atau mengevaluasi informasi. Informasi tersebut bisa didapatkan dari hasil pengamatan, pengalaman, akal sehat atau komunikasi. Berpikir kritis juga merupakan sebuah proses sistematis yang memungkinkan siswa untuk merumuskan dan mengevaluasi keyakinan dan pendapat mereka sendiri. Kemampuan berpikir kritis setiap individu berbeda antara satu dengan lainnya sehingga perlu dipupuk sejak dini.Seseorang yang berpikir kritis memiliki karakter khusus yang dapatdiidentifikasi dengan melihat bagaimana seseorang menyikapi suatu masalah.Informasi atau argumen karakter-karakter tersebut tampak pada kebiasaan bertindak, beragumen dan memanfaatkan intelektualnya dan pengetahuannya.

Peranan pembelajaran matematika salah satunya adalah untuk membentuk kemampuan berpikir matematis siswa yang bermanfaat tidak hanya digunakan di sekolah tetapi juga bermanfaat dalam menghadapi masalah sehari-hari. Dalam proses pembelajaran di kelas, untuk membiasakan siswa berpikir kritis, guru perlu melakukan inovasi pembelajaran dengan menerapkan suatu metode atau strategi pembelajaran. Inovasi ini perlu dilakukan, agardapat pada pembelajaran matematika, guru dapat mendorong peningkatan kemampuan berpikir matematis siswa. Salah satu strategi pembelajaran yang dapat diterapkan adalah dengan melakukan pembiasaan (habits) dengan masalah-masalah yang dapat meningkatkan kemampuan berpikir matematisnya.

Mathematical Habits of Mind (MHM) adalah suatu strategi yang dapat digunakan dalam pembelajaran, guna membiasakan diri berpikir matematis. Strategi MHM ini dikembangkan oleh Millman dan Jaccobe dalam penelitiannya tahun 2008 untuk mengembangkan kemampuan berpikir kreatif (Mahmudi dan Sumarmo, 2009). Menurut Market al. (2010),Mathematical Habits of Mindadalah menjelaskan keteraturan pada perhitungan dan melakukan generalisasi dengan menggunakan bahasa matematika. Cuocoet al. (2010) menyatakan Mathematical 
Habits of Mind pada siswa SMA adalah mempelajari eksperimen pemikiran; menemukan, mengartikulasikan, dan menjelaskan pola; membuat dan menggunakan representasi; generalisasi dari contoh; mengasosiasikan generalisasi dalam bahasa yang tepat; menjelaskan matematika untuk mudah dimengerti.

Hasil penelitian yang dilakukan Mahmudi dan Sumarmo (2009)menunjukkan bahwa strategi MHM berbasis masalah dapat meningkatkan kemampuan berpikir kreatif siswa. Salah satu alasan yang menunjukan hasil tersebut adalah kebiasaan-kebiasaan mengeksplorasi ide-ide matematis dalam rangkaian pembelajaran dengan strategi MHM berbasis masalah mendorong siswa berpikir fleksibel. Hal inilah yang menjadi salah satu keunggulan strategi MHM berbasis masalah dibandingkan dengan pembelajaran biasa. Kemampuan berpikir kreatif dan berpikir kritis sangat berkaitan satu sama lain. Seseorang yang memiliki kreativitas dalam memperoleh solusi permasalahan harus kritis untuk dapat mengambil keputusan dalam menentukan solusi mana yang tepat dalam menyelesaikan masalah yang dihadapinya.

Selain melakukan kebiasaan berpikir matematik dengan strategi MHM, pembelajaran yang pada hakekatnya adalah proses komunikasi akan lebih efektif bila di dalamnya menggunakan suatu media berupa multimedia.Multimedia merupakan suatu media yang mengombinasikan teks, grafik, gambar, animasi dan audio. Penggunaan multimedia ini bertujuan untuk mempermudah siswa mempelajari setiap materi dan mempermudah proses belajarnya dalam setiap aktivitas yang dilakukan. Salah satu gambaran yang paling banyak dijadikan acuan penggunaan media dalam proses belajar adalah Dale's Cone Experience atau Kerucut Pengalaman Dale (Arsyad, 2011).

Dalam kerucut pengalaman Edgar Dale digambarkan bahwa tingkat keabstrakan pesan atau materi akan semakin tinggi ketika pesan disajikan ke dalam lambang-lambang kata saja. Sedangkan tingkat kekonkretan akan naik ketika pesan disampaikan sebagai pengalaman langsung. Karena, keterlibatan fisik atau alat indera siswa berperan penting di dalamnya. Semakin banyak partisipasi fisik siswa dalam belajar maka semakin mudah bagi siswa memahami pesan atau materi yang disampaikan (Arsyad, 2011). 
Uraian di atas menunjukkan bahwa strategi MHM berbantuan multimedia berpotensi untuk meningkatkan kemampuan berpikir kritis siswa. Hal demikian mendorong peneliti untuk mengintegrasikan pembelajaran berbasis ICT (multimedia) dengan strategi MHM. Melalui pembelajaran demikian, secara kolaboratif siswa melakukan kebiasaan-kebiasaan berpikir matematis untuk mengeksplorasi masalah, fakta, informasi, data, atau strategi penyelesaian masalah. Siswa juga belajar untuk mengkontruksi contoh dan memformulasi pertanyaan terkait dengan pengetahuan yang telah dibangun atausoal yang telah diselesaikan.

Oleh karena itu, peneliti ingin melakukan suatu penelitian dengan menggunakan strategi MHM berbantuan multimedia untuk meningkatkan kemampuan berpikir kritis siswa.Adapun tujuan penelitian ini adalah untuk mengkaji apakah peningkatan kemampuan berpikir kritis siswa menggunakan strategi pembelajaran Mathematical Habits of Mind (MHM) berbantuan multimedia lebih baik daripada menggunakan strategi pembelajaran saintifik dan untuk mengetahui bagaimana sikap siswa terhadap pembelajaran menggunakan strategi Mathematical Habits of Mind (MHM) berbantuan multimedia.

\section{METODE PENELITIAN}

Penelitian ini merupakan penelitian eksperimen kuasi. Menurut Arikunto (2010: 123), eksperimen kuasi merupakan jenis eksperimen yang belum memenuhi persyaratan seperti cara eksperimen yang dapat dikatakan ilmiah yang mengikuti peraturan-peraturan tertentu. Sebab penelitian ini dilakukan tanpa mengontrol semua variabel dan subjek tidak dipilih secara random (nonrandom sampling).

Pada penelitian ini kelompok eksperimen mendapatkan pembelajaran dengan menggunakan strategi MHM berbantuan multimedia, sedangkan kelompok kontrol menggunakan pembelajaran saintifik.Desain penelitian yang dipilih adalahPretest Posttest Control Group Design.

Populasi pada penelitian ini adalah SMA Negeri di Cianjur dengan sampel adalah kelas X IIS 4 sebagai kelas eksperimen, dan kelas X IIS 2 sebagai kelas kontrol.Teknik sampling yang penelitian ini adalah purposive sampling. Menurut Lestari dan Yudhanegara (2015: 110) purposive sampling adalah teknik penentuan 
sampel dengan pertimbangan atau tujuan (kriteria) tertentu. Banyaknya siswa kelas eksperimen adalah 33 siswa dan kelas kontrol adalahsebanyak 34 siswa.

Tes kemampuan berpikir kritis matematis terdiri atas 6 butir soal uraian untuk mengukur aspek-aspek kemampuan berpikir kritis matematis siswa, yaitu (1) memberikan penjelasan sederhana (elementary clarification), (2) membuat penjelasan lebih lanjut (advances clarification), (3) menentukan strategi dan taktik (strategy and tactics) untuk menyelesaikan masalah, (4) membuat simpulan (inference), dan (5) membangun keterampilan dasar (basic support). Setiap butir soal mewakili masing-masing aspek. Namun terdapat dua butir soal yang memuat dua aspek atau indikator bersamaan, yaitu butir soal nomor 3 dan 4 memuat indikator (3) dan (4). Kemudian ada juga dua butir soal yang memuat indikator yang sama, yaitu butir soal nomor 5 dan 6 yang memuat indikator (5). Hal ini disesuaikan dengan kebutuhan dan kecocokkan materi dengan indikator kemampuannya. Seperti butir soal nomor 3 dan 4 yang berbentuk soal cerita memuat 2 indikator karena di dalamnya siswa harus dapat menentukan strategi dan taktik penyelesaian masalah juga perlu menarik kesimpulan.

Metode yangdigunakan untuk memperoleh data yaitu tes, kuesioner/ angket dan jurnal harian siswa. Metode tes digunakan untuk memperoleh data kemampuan awal (prestest) dan kemampuan setelah diberikan treatment/ tindakan. Sedangkan kuesioner/angket digunakan untuk mengetahui bagaimana sikap siswa terhadap pembelajaran setelah diberikan pembelajaran dengan strategi MHM berbantuan multimedia. Angket skala sikap siswa terhadap pembelajaran menggunakan strategi MHM berbantuan multimedia terdiri atas 20 butir pernyataan masing-masing dengan 4 kategori pilihan, yaitu sangat setuju, tidak setuju, dan sangat tidak setuju. Jurnal harian digunakan sebagai instrumen pendukung untuk mengetahui respon siswa terhadap proses pembelajaran setiap pertemuannya, juga berguna untuk mengevaluasi guru dalam proses menyampaikan materi.

\section{HASIL DAN PEMBAHASAN}


Berdasarkan hasil analisis data pretest diperoleh data yang menunjukkan bahwa kedua kelas yang diambil sebagai sampel berasal dari populasi yang tidak berdistribusi normal. Kemudian dilakukan uji non-parametrik Mann Withney, diperoleh hasil bahwa sampel memiliki kondisi atau keadaan yang cenderung sama yaitu memiliki pengetahuan awal yang sama. Secara deskriptif, perbedaan rata-rata skor pretest kedua kelas adalah 0,39 lebih besar kelas X IIS 2. Berdasarkan hasil analisis tersebut maka dipilih kelas X IIS 4 sebagai kelas ekperimen dan X IIS 2 sebagai kelas kontrol.

Pada kelas eskperimen diterapkan pembelajaran dengan strategi MHM berbantuan multimedia. Sedangkan pada kelas kontrol dilakukan pembelajaran dengan menggunakan pendekatan saintifik. Setelah diberi perlakuan, diperoleh data kemampuan berpikir kritis pada kedua kelas. Secara deskriptif data analisis menggunakan software SPSS 20 for Windows disajikan dalam tabel berikut.

Tabel 1. Statistik Deskriptif Posttest

\begin{tabular}{lcccccc}
\hline \multicolumn{1}{c}{ Kelas } & N & Rata-rata & Std. dev. & Skor Min. & Skor Maks. & SMI \\
\hline Kontrol & 34 & 10,61 & 2,82 & 6 & 18 & 24 \\
\hline Eksperimen & 33 & 14,73 & 3,25 & 7 & 21 & 24 \\
\hline
\end{tabular}

Berdasarkan tabel di atas, secara deskriptif, perbedaan rata-rata kedua kelas adalah 4,12. Untuk mengetahui apakah rata-rata posttets kedua kelas berbeda secara signifikan atau tidak maka dilakukan uji statistik. Hasil yang diperoleh dari uji normalitas data posttets adalah bahwa kelas kontrol berdistribusi normal, sedangan kelas eksperimen tidak berdistribusi normal.

Tabel 2. Hasil Uji Mann-Whitney Posttest

\begin{tabular}{ccc}
\hline Data Posttest & $\begin{array}{c}\text { Asymp Sig. } \\
(2 \text {-tailed })\end{array}$ & Ket. \\
\hline Eksperimen & 0,000 & $\mathrm{H}_{0}$ ditolak \\
\hline Kontrol & & \\
\hline
\end{tabular}

Dikarenakan salah satu sampel berasal dari populasi yang tidak berditribusi normal, maka selanjutnya dilakukan uji non-parametrik Mann-Whitney. Dari hasil uji Mann-Whitney diperoleh kesimpulan bahwa rata-rata pencapaian kemampuan berpikir kritis siswa kelas eksperimen lebih baik daripada kelas kontrol.Untuk mengetahui peningkatan indikator kemampuan berpikir kritis siswa dilakukan 
analisis terhadap data dari rata-rata skor untuk setiap butir soal. Adapun rincian indikator kemampuan berpikir kritis dan nomor soal pada instrumen yang telah digunakan disajikan pada tabel berikut.

Tabel 3.Data Nomor Soal dan Indikator Kemampuan Berpikir Kritis

\begin{tabular}{lcc}
\hline \multicolumn{1}{c}{ Indikator } & $\begin{array}{c}\text { Nomor } \\
\text { Soal }\end{array}$ \\
\hline $\begin{array}{l}\text { Memberikan penjelasan sederhana (elementary clarification) } \\
\text { Membuat penjelasan lebih lanjut (advances clarification) }\end{array}$ & 1 \\
\hline $\begin{array}{l}\text { Menentukan strategi dan taktik (strategy and tactics) } \\
\text { menyelesaikan masalah. }\end{array}$ & untuk & $3 \mathrm{dan} 4$ \\
\hline \begin{tabular}{l} 
Membuat simpulan (inference) \\
\hline Membangun keterampilan dasar (basic support)
\end{tabular} & $3 \mathrm{dan} 4$ \\
\hline
\end{tabular}

Untuk mengetahui indikator kemampuan berpikir kritis siswa mana yang memiliki peningkatan tertinggi dalam pembelajaran dengan strategi MHM berbantuan multimedia dibandingkan dengan siswa yang memperoleh pembelajaran dengan pendekatan saintifik, maka dilakukan pengolahan data dengan menggunakan bantuan Microsoft OfficeExcel 2016.Data yang digunakan adalah data gain ternormalisasi (N-gain) siswa per butir soal yang diujikan, kemudian data tersebut dirata-ratakan sehingga diperoleh hasil data sebagai berikut.

Tabel 4. Hasil Analisis Rata-rata N-Gain per Butir Soal

\begin{tabular}{ccccc}
\hline No. Soal & $\begin{array}{c}\text { Rata-rata } \\
\text { N-gain } \\
\text { Kls Eksp. }\end{array}$ & Kateg. & $\begin{array}{c}\text { Rata-rata } \\
\text { N-gain } \\
\text { Kls Kntrl }\end{array}$ & Kategori \\
\hline $\mathbf{1}$ & 0,82 & Tinggi & 0,31 & Sedang \\
\hline $\mathbf{2}$ & 0,36 & Sedang & 0,30 & Rendah \\
\hline $\mathbf{3}$ & 0,68 & Sedang & 0,44 & Sedang \\
\hline $\mathbf{4}$ & 0,48 & Sedang & 0,09 & Rendah \\
\hline $\mathbf{5}$ & 0,50 & Sedang & 0,47 & Sedang \\
\hline $\mathbf{6}$ & 0,53 & Sedang & 0,45 & Sedang \\
\hline
\end{tabular}

Dari Tabel 3. diperoleh hasil rata-rata $N$-Gain kelas eksperimen tertinggi adalah 0,82 pada butir soal nomor 1 , yaitu pada indikator memberikan penjelasan sederhana (elementary clarification). Sedangkan pada kelas kontrol, terdapat nilai $\mathrm{N}-$ Gain terendah yaitu 0,09 pada butir soal nomor 4. Nilai 0,09 menunjukkan kriteria N-Gain yang rendah. Selain itu, pada butir soal nomor 2, rata-rata nilai NGainnya sebesar 0,30, termasuk kriteria N-Gain rendah. Jadi, pada kelas kontrol terdapat nilai N-Gain yang rendah yaitu pada butir soal nomor 2 yang memuat PRISMA 
indikator membuat penjelasan lebih lanjut (advances clarification), dan juga pada butir soal nomor 4 yang memuat indikator menentukan strategi dan taktik (strategy and tactics) untuk menyelesaikan masalah dan membuat kesimpulan (inference).

Pembelajaran dengan menggunakan strategi MHM berbantuan multimedia mengalami peningkatan kemampuan berpikir kritis siswa di kelas eksperimen terutama untuk indikator yang pertama pada butir soal nomor 1 , dan indikator lainnya mengalami peningkatan dengan kategori sedang. Begitu juga pembelajaran dengan pendekatan saintifik pada kelas kontrol, semua indikator mengalami peningkatan. Namun pada butir soal nomor 2 dan nomor 4, kategori peningkatannya rendah. Jika dilihat dari nilai rata-rata N-Gain setiap butir soal, peningkatan setiap indikator berpikir kritis melalui strategi MHM berbantuan multimedia lebih tinggi daripada peningkatan berpikir kritis melalui pendekatan saintifik.

Adapun kemungkinan faktor-faktor yang menjadi penyebab perbedaan yang signifikan anatara pencapaian dan peningkatan kemampuan berpikir kritis matematis siswa yang mendapat pembelajaran dengan stratgei MHM berbantuan multimedia dengan siswa yang mendapat pembelajaran dengan pendekatan saintifik adalah sebagai berikut.

1. Pada pembelajaran dengan strategi MHM, guru menyediakan pengalaman belajar yang dirancang dalam bentuk diskusi kelompok/ berpasangan disertai LKS yang dapat membantu siswa dalam memahami materi dan membangun pengetahuannya sendiri dengan bimbingan guru. Selain itu, materi pembelajaran diilustrasikan dalam bentuk tayangan Power Point semenarik mungkin, menggunakan animasi-animasi yang membuat siswa antusias memperhatikan materi, terutama dalam mambahas soal-soal cerita. Penggunaan multimedia memudahkan siswa dalam memahami materi yang awalnya abstrak, menjadi lebih konkret. Menurut Reiber, bagian penting lain pada multimedia adalah animasi, karena berdasarkan penelitian, siswa yang memiliki latar belakang pendidikan dan pengetahuan yang rendah cenderung memerlukan bantuan, salah satunya animasi untuk menangkap konsep materi yang disampaikan (Susilana dan Riyana, 2009: 100). Akibatnya, siswa lebih mudah mengingat materi yang telah dipelajari. 
2. Kemampuan berpikir kritis erat kaitannya dengan perumusan masalah, penyelidikan, bertanya sebagai salah satu bentuk mengkritisi masalah, mengevaluasi, dan juga menyimpulkan. Pada pembelajaran dengan strategi MHM membuat siswa terbiasa untuk mengeksplorasi ide-ide matematis dengan menuliskan informasi yang diketahui dan informasi apa yang belum diketahui disoal. Selanjutnya informasi tersebut digunakan untuk menentukan strategi yang cocok dalam menyelesaikan soal. Selain itu siswa dilatih untuk terbiasa mengajukan pertanyaan-pertanyaan kritis berkenaan dengan materi pelajaran, dibiasakan mengkontruksi contoh, dan dibiasakan untuk dapat menggeneralisasi atau menarik kesimpulan sesuai permasalahan yang ada. Pembelajaran dengan strategi MHM dapat mengembangkan kemampuan berpikir kritis matematis bagi siswa bila dilakukan secara konsisten dan berkelanjutan.

3. Indikator yang meningkat pada kategori tinggi melalui strategi pembelajaran MHM berbantuan multimedia adalah indikator memberikan penjelasan sederhana (elementary clarification) pada butir soal nomor 1. Pada kelas kontrol, yang meningkat dengan kategori sedang adalah butir soal nomor 1 dengan indikator memberi penjelasan sederhana, butir soal nomor 3 dengan indikator menentukan strategi peneyelasaian masalah dan menyimpulkan, serta butir soal nomor 5 dan 6 dengan indikator membangun keterampilan dasar. Namun, pada butir soal nomor 2 dengan indikator membuat penjelesan lebih lanjut, peningkatan di kelas kontrol memiliki kategori yang rendah. Hal ini mungkin disebabkan karena siswa tidak terbiasa untuk mengekplorasi ide-ide matematis yang ada pada soal, seperti menggunakan gambar segitiga yang sudah diketahui disoal dalam menentukan nilai Trigonometri untuk sudut $30^{\circ}$ dan $60^{\circ}$. Siswa di kelas kontrol sebagian besar langsung mengisi soal tersebut dengan hapalan yang mereka miliki, tanpa tahu dari mana mereka bisa memperoleh nilai-nilai tersebut. Kemudian untuk butir soal nomor 4, kategori peningkatannya pun rendah. Hal ini juga dapat disebabkan siswa tidak terbiasa untuk menemukan informasi lain yang dibutuhkan dan belum diketahui di soal. Siswa cenderung mengolah data atau informasi yang sudah ada pada soal, dan ketika ada informasi yang kurang siswa merasa kesulitan. Selain itu, siswa tidak terbiasa untuk 
mencantumkan penarikan kesimpulan, khususnya ketika menyelesaian soal cerita. Sedangkan pada kelas eksperimen butir soal nomor 2 sampai dengan nomor 6 mengalami peningkatan dengan kategori sedang. Meskipun ketika pretest siswa merasa kesulitan dan mengalami kesalahan dalam perhitungan menjawab butir soal nomor 4, dan sebagian besar tidak menjawab pada butir soal nomor 5 dan 6, akan tetapi setelah diberikan treatment, dengan langkah-langkah strategi MHM dibantu dengan penggunaan multimedia, pada umumnya mereka dapat menjawab soal dengan benar ketika . Pada butir soal nomor 6, siswa yang awalnya tidak menjawab sama sekali, setelah dibiasakan dan dilatih keterampilan dasarnya dalam menemukan ide untuk menyelesaikan soal identitas trigonometri, mereka dapat menyelesaikan soal dengan baik.

Berdasarkan analisis angket siswa, strategi MHM berbantuan multimedia pada pembelajaran matematika memperoleh respon sikap yang positif. Hal ini kemungkinan disebabkan karena siswa merasa mudah dalam menyelesaikan soal dengan langkah-langkah yang dibiasakan oleh guru setiap pertemuannya. Selain itu, materi yang disajikan dalam LKS dan dalam bentuk tayangan Power Point membuat siswa antusias dalam belajar karena materi disajikan semenarik mungkin agar siswa selalu bersemangat dalam belajar. Siswa pun bebas mengajukan pertanyaan dan mengemukakan pendapat meskipun awalnya mengalami kesulitan karena masih merasa malu dan belum terbiasa. Sikap siswa selama pembelajaran terlihat selama proses pembelajaran berlangsung yang dituangkan dalam jurnal harian siswa, siswa terlibat aktif selama pembelajaran, dan guru pun memberikan pembelajaran sesuai langkah-langkah pembelajaran yang diharapkan.

\section{KESIMPULAN}

Dari hasil penelitian yang telah dilaksanakan, dapat disimpulkan bahwa (1) peningkatan kemampuan berpikir kritis matematis siswa yang menggunakan strategi pembelajaran Mathematical Habits of Mind (MHM) berbantuan multimedia lebih baik daripada siswa yang menggunakan strategi pembelajaran saintifik; (2) sikap siswa terhadap pembelajaran setelah mendapatkan pembelajaran menggunakan strategi MHMberbantuan multimedia adalah baik atau positif. Oleh 
karena itu penggunaan strategi Mathematical Habits of Mind (MHM) dapat digunakan sebagai salah satu alternatif untuk meningkatkan kemampuan berpikir kritis siswa, dan didukung dengan pemanfaatan teknologi seperti penggunaan multimedia dalam proses pembelajaran.

\section{REFERENSI}

Arikunto, S. (2010). Prosedur Penelitian Suatu Pendekatan Praktik, Edisi Revisi Jakarta: Rineka Cipta.

Arsyad, A. (2011). Media Pembelajaran. Jakarta: PT. Raja Grafindo Persada.

Costa, A. (2001). Developing minds: a resource book for teaching thinking. Alexandria. VA:Association for supervision and Curriculum Development.

Cuoco, A., Goldenberg, E. P., \& Mark, J. (2010). Contemporary curriculum issues: Organizing acurriculum around mathematical habits of mind. Mathematics Teacher, 103(9), 682-688.

Facione, P. A. (2011). Critical Thinking: What It Is and Why It Counts. [Online]. Diakses dari http://www.student.uwa.edu.au [19 September 2016]

Lestari, K. E. dan Yudhanegara, M. R. (2015). Penelitian Pendidikan Matematika (Panduan Praktis Menyusun Skripsi, Tesis, dan Laporan Penelitian dengan Pendekatan Kuantitatif, Kualitatif, dan Kombinasi Disertai Model Pembelajaran dan Kemampuan Matematis). Bandung: PT. Refika Aditama.

Mahmudi, A. (2009). Strategi Mathematical Habits of Mind (MHM) untuk Mengembangkan Kemampuan Berpikir Kreatif Matematis. Makalah Disampaikan pada Konferensi Nasional Pendidikan Matematika III UNM, Medan. [Online]. Diakses dari:http://staff.uny.ac.id/sites/default/files/ penelitian/ Ali\% 20Mahmudi. [19 Mei 2016].

Mahmudi, A. dan Soemarmo, U. (2009). Pengaruh Strategi Mathematical Habits of Mind (MHM) Berbasis Masalah terhadap Kreativitas Siswa. Jurnal UNY.[Online]. Diakses darihttp://journal.uny.ac.id/index.php/cp/ article/ view/4229/pdf. [19 Mei 2016].

Mark, J., Cuoco, A., Goldenberg, E. P., \& Sarah S. (2010). Contemporary curriculum issues:Developing mathematical habits of mind. Mathematics Teaching in the Middle School,15 (9), 505-509.

Murtiyasa, B. (2015). Tantang Pembelajaran Matematika Era Global. Prosiding Seminar Nasional Matematika UMS 2015, [Online]. Diakses darihttps://publikasiilmiah.ums.ac.id/handle/11617/6005.[15 Januari 2017].

Shadaika, M. (2015). Pengaruh Model Project Based Learning berbasis Potensi Makroalga Daerah Pesisir terhadap Kemampuan Berpikir Kritis Siswa pada Materi Ekosistem di SMA Negeri 1 Tanjungsari Gunungkidul DIY. Tesis, Fakultas Keguruan dan Ilmu Pendidikan UNS. [Online]. Diakses darihttp://eprints.uns.ac.id/18448/2/BAB_1.pdf.[19 Mei 2016].

Susilana, R. dan Riyana, C. (2009). Media Pembelajaran. Bandung: CV Wacana Prima. 